\title{
Modern Literature as a Form of Discourse and Knowledge of Society
}

\section{Erkki Sevänen*}

\begin{abstract}
Since the 1960's, epistemological skepticism and constructionism have had a firm position in literary studies. Structuralism's late phase, post-structuralism, certain sub-branches of current narratology, and certain representatives of recent sociology of literature, in particular, have maintained this sort of philosophical line of thought in literary studies. According to it, literature's epistemic function can chiefly lie in that it possibly helps us to deconstruct different discourses or world views and to understand their strengths and weaknesses. The article argues for the view that these research trends operate with a unidimensional conception of reality and with a questionable version of constructionism. Hence, they do not understand the specificity of societal-cultural reality and social actors' specific epistemic relation to it. On this basis, modern literature can be seen as a discursive practice with epistemic and evaluative properties. It is a practice that usually deals with the problems that are caused by the development of societal-cultural reality and that are felt personally important by the authors of literary texts. Often it is just literary texts that first give a public expression to problems such as these.
\end{abstract}

Keywords: knowledge, skepticism, constructionism, discursive practice, values.

*University of Eastern Finland, Joensuu. North Karelia, Finland 


\section{Literatura moderna como forma de discurso y de conocimiento sobre la sociedad}

\section{Resumen}

Desde la década de 1960, el escepticismo epistemológico y el construccionismo se han consolidado en los estudios literarios. La fase tardía del estructuralismo, el posestructuralismo, ciertas subdivisiones de la narratología actual y ciertos representantes de la sociología reciente de la literatura, en particular, han mantenido este tipo de línea filosófica de pensamiento en los estudios literarios. Según esta corriente, la función epistémica de la literatura estaría radicada principalmente en su capacidad de ayudar a deconstruir diferentes discursos o visiones de mundo y a comprender sus fortalezas y debilidades. Este artículo sostiene que tales tendencias de investigación operan con una concepción unidimensional de la realidad y con una versión cuestionable del construccionismo. Por lo tanto, no logran captar la especificidad de la realidad sociocultural, ni la relación epistémica específica de los actores sociales con esta realidad. A partir de ahí, se puede ver la literatura moderna como una práctica discursiva con propiedades epistémicas y evaluativas. Es una práctica que, en general, se ocupa de los problemas causados por el desarrollo de la realidad sociocultural, los cuales son vistos subjetivamente por los autores de los textos literarios como importantes. A menudo son los textos literarios los que por primera vez expresan públicamente tales problemas.

Palabras clave: conocimiento, escepticismo, construccionismo, práctica discursiva, valores. 


\section{Introduction}

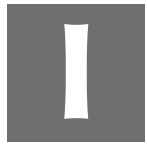

n his well-known study, Le Capital au XXIe siècle (2013), the French economist Thomas Piketty praises the $19^{\text {th }}$ century European literature's way of representing society and its huge class inequalities. In particular, Piketty has in his mind Honoré de Balcaz's (1799-1850) and Jane Austen's (1775-1817) novels that describe the effects of the $19^{\text {th }}$ century's sharp class hierarchies "with a verisimilitude and evocative power that no statistical or theoretical analysis can match" (Piketty, 2014, pp. 2, 53-4, 105-6, 113-6). In these respects, those novels offer us even a more accurate picture of the $19^{\text {th }}$ century class society than the social and historical sciences are capable of doing.

Literary scientists do not necessarily share Piketty's view. Since the latter half of the twentieth century, literary studies have widely abandoned the thought that literary works could offer us genuine knowledge of the world. This type of skepticism concerning literature was not characteristic of traditional research streams such as biographical positivism, Marxism and classical structuralism that used to emphasize literature's epistemic and cognitive value. However, already in structuralism's late phase, especially, in Umberto Eco's Opera aperta (1962) and Roland Barthes' S/Z (1970) literature ceases to be an epistemic route to the world, although it is still, in these two works, capable of problematizing different views of the reality. Post-structuralism has been a continuation to these works. Due to it, a strong breath of constructionism spread out to academic communities in the Western world in the 1970s and 1980s. Albeit post-structuralism's golden age ended in the 1990s, constructionist epistemology is still influencing literary studies. This manifests itself, for instance, in current or "post-classical" narratology certain branches of which understand narratives as human constructs that project a sensible order onto the reality. In this sense, David Herman (2003a; 2003b), Louis O. Mink (1970), Galen Strawson (2004) and 
Hayden White (1987), among others, have seen an obvious incongruity between narratives and the reality.

Cognitive sciences and their applications in literary studies could, in principle, mean a more clear-cut estrangement from a strong constructionism. Because cognitive sciences have, by means of an empirical and experimental research work, focused on studying human mind and its ways of functioning, their applications in literary studies have laid stress on literature's cognitive and intellectual dimension. Unfortunately, so far they have, however, largely excluded epistemic and epistemological questions outside their horizon. This article elaborates upon a stand that understands modern literature as a discursive phenomenon with epistemic properties. I am aware of that recently literary scholars have favored a more skeptical view of literature's epistemic value, but, as I will show, the stand in question receives support from the literary studies, philosophy and sociology practiced since the beginning of the $20^{\text {th }}$ century. The structure of this article is as follows.

First, I consider the culture of epistemological skepticism and constructionism in literary studies and its neighbor disciplines. This culture has not been represented only by Barthes, Eco and post-structuralists but also by certain sociologists (Niklas Luhmann) and sociologically-oriented literary scholars (Terry Eagleton, Siegfried J. Schmidt). The latter observation indicates that a sociological approach in literary studies is not always connected to a positive view of literature's epistemic potentialities. With certain reservations, classics of the sociology of literature such as Georg Lukács, Theodor W. Adorno and Fredric Jameson regarded literature as a special form of knowledge of society, but their successors have often been more skeptical in this respect. This concerns, especially, Luhmann and Schmidt who have stood for constructionist thinking in the sociology of art and literature. As for Eagleton, his views cannot be equated with constructionism, but he has estranged himself from Lukács and Adorno, as well. 
What is questionable in the above-mentioned constructionist thinking? When formulating their epistemological stands, representatives of this thinking do not usually distinguish between physical nature and societal-cultural reality. This neglect has negative implications, since it ignores that societal-cultural reality does not consist only of abstract structures, concrete things and people's physical behavior but also of meanings, rules, norms and values steering people's behavior. Hence, social actors have a more or less systematic preknowledge of the world in which they live and act, since - in order to be able to act in this world - they have to internalize its central meanings, rules and values. In this sense, there does not exist an entirely insuperable epistemic wall between social actors, including social scientists, and the social world.

This sort of two-dimensional conception of societal-cultural reality has been common in hermeneutic-phenomenological philosophy in which Wilhelm Dilthey, Heinrich Rickert and Wilhelm Windelband laid its foundation at the turn of the $19^{\text {th }}$ and $20^{\text {th }}$ centuries. Later, in particular, Edmund Husserl, Martin Heidegger, Hans-Georg Gadamer, Ludwig Wittgenstein's late production, Peter Winch, lan Hacking and Paul Ricoeur elaborated on it in philosophy, while in sociology it has been worked on by figures such as Max Weber, Georg Simmel, Alfred Schütz, Jürgen Habermas, G.H. Mead, Harold Garfinkel and Anthony Giddens. In literary studies, hermeneutic-phenomenological tradition was eclipsed by structuralist and post-structuralist thinking in the latter half of the $20^{\text {th }}$ century. At present, literary studies live still in the aftermaths of these two influential intellectual traditions. In part, as a result of this, it has a quite underdeveloped view of literature's function in society, nor does it correctly understand literature's epistemic dimensions. This article stands for the sociology of literature - a branch of research that forms an overlapping area between literary studies and sociology. The sociology of literature should, therefore, be capable of answering to the question in what ways modern literature deals with societal-cultural reality and what kind of knowledge of it modern literary 
works offer us. By "modern literature" the article chiefly means Western literature from the $18^{\text {th }}$ century on. It was just in the $18^{\text {th }}$ century that Western literature detached itself from the classical paradigm, i.e. from a strong dependency on antiquity and the Bible and began to describe its own time and the surrounding social world.

After this the article clears up in what ways modern literature has dealt with society. The article does not consider modern literary works as abstract linguistic-narrative entities but as communicative acts between authors and society. Modern literature constitutes, thereby, a discursive field or practice that usually deals with the philosophical, moral, social and individual problems caused by the development of societal-cultural reality; in modern culture, it has belonged to the tasks of literature to bring up problems like these and to make society more clearly aware of them. By considering certain single literary works in more detail, the article shows how this sort of communication between literature and societal-cultural reality has come true concretely.

\section{Skepticism and constructionism in literary studies and in its neighbor disciplines}

In traditional literary studies, biographical positivism, Marxism and structuralism had an unproblematic philosophical view of knowledge, as they did not question human mind's ability to make reliable perceptions and descriptions of the world. According to Eco's Opera aperta and Barthes' S/Z, a similar epistemological conception underlies traditional realistic-naturalistic literature that dominated modern Western literary culture from the 1830 s to the beginning of the $20^{\text {th }}$ century. In France, Balzac and Émile Zola (1840-1902) were perhaps its most appreciated representatives. In the above-mentioned studies, Eco and Barthes show their dissatisfaction with this tradition.

Eco's and Barthes' own literary ideals fastened on French nouveau roman whose representatives - Alain Robbe-Grillet (1922-2008), Nathalie 
Sarraute (1900-1999), Claude Simon (1913-2005) - reflect in their novels on literature's linguistic and narrative means, besides which they abandoned traditional plot and psychologically many-sided characters. Barthes writes that in comparison with this modernist or avant-gardist literature, traditional realistic-natural literature covers the means by which it constructs a picture of society. It is "invisible literature" that aims at arousing "a reality effect" in readers, i.e. it arouses an illusion that it merely let the reality manifest itself or happen in literature. For Barthes (1970, pp. 11-2, 36, 206, 227), this procedure is ideological, since it is incompatible with his skeptic or agnostic epistemology. He did not only question language's and literature's ability to represent reality adequately, but he also doubted whether human knowledge can catch the reality as such. Because realistic-naturalistic literature arouses the impression that it is able to do this, Barthes concluded that it only "pretends" to be an objectively true picture of society.

$S / Z$ has also been placed to the domain of post-structuralism. In post-structuralist thinking, realism and naturalism have been understood as narrative conventions that do not possess an epistemologically privileged position in literature. In this constellation, literature's societal-critical function lies chiefly in that it can question different ways of representing the reality, i.e. it can show them as human constructs and reveal what sort of epistemological and ideological engagements underlie them. Traditional realistic-naturalistic literature is here defined as an epistemologically questionable and literary obsolete way of representing the reality.

At a philosophical level, representatives and adherents of poststructuralism have usually supported constructivist conceptions of knowledge. Their constructionism has had two important sources, Michel Foucault's social theory, on the one hand, and Jacques Derrida's philosophical wirings, on the other hand. In his works Surveiller et punir: naissance de la prison (1975) and Histoire de la sexualité. La première partie (1976) Foucault launched the idea that "a will to knowledge" cannot be separated from 
"a will to power". Quite often this idea has been understood to deny the possibility of genuine or pure knowledge. Albeit it is unclear, whether Foucault would himself have been ready to give his unreserved approval to this interpretation, the "Foucaultian idea" of the union between power and knowledge-seeking has had an enormous influence on constructivist thinking in the social sciences and the humanities. A similar ambiguity concerns Derrida's influence. In his De la grammatologie (1967), especially, Derrida presented a thought that "there is nothing outside the text". The meaning of this thought remains unspecified in the work at issue, but it has usually been supposed to mean that knowledge is necessarily concept-bound or discourse-bound. Owing to this bond, adherents of post-structuralism have emphasized, we cannot know what the reality is as such; instead, we can only know how it manifests itself in our discourses and concepts.

Through this, post-structuralism rejected realistic epistemology and the possibility of objective knowledge, and it has stood for agnosticism or skepticism in matters of knowledge. Post-structuralism's representatives and adherents in literary studies have, in particular, admired Derrida's writings, because they seem to treat science, philosophy and literature basically in the same way, i.e. as three different genres of writing and rhetorical persuasion. For the same reason post-structuralists and their adherents have conceived of Friedrich Nietzsche as their intellectual forefather. In the $19^{\text {th }}$ century's intellectual atmosphere dominated by scientism, it was, above all, Nietzsche who first expressed a deep distrust in a world view of scientism. This happened, for example, in his writing "Über Wahrheit und Lüge im aussermoralischen Sinn" (1873) in which he answers to the question "What then is truth?" as follows:

A movable host of metaphors, metonymies, and anthropomorphisms: in short, a sum of human relations which have been poetically and rhetorically intensified, transferred, and embellished, and which, after long usage, seem to a people to be fixed, canonical, and binding. Truths are illusions which we have forgotten are illusions (Nietzsche, p. 2006, 117). 
Thereby the dichotomy between facts and interpretations or between science and myths would, in the last resort, be epistemologically groundless, and the idea of truth would, in itself, be an unattainable ideal. Several poststructuralists have, in their writings, worked on this thought. For example, in his Allegories of Reading (1979) Paul de Man, in a manner à la Nietzsche und Derrida, rejects all kinds of simple oppositions between "philosophy" and "rhetoric" or between "philosophy" and "literature" (see also Norris, 1988, p. 64-101). Albeit post-structuralists have emphasized that there is not either a clear-cut boundary between the outside and the inside of a literary text, i.e. between the object and the subject in literary studies, most of them have - like de Man - dealt with literary texts in an argumentative way. In this respect, Geoffrey H. Hartman (1980), with his highly individual way of dealing with literature, has not been their most typical representative.

Post-structuralism's constructionism is, primarily, epistemological by nature, but it also contains an element of social constructionism. Epistemological constructionism does not regard human knowledge as a mirror of the reality but as a more or less creative interpretation of it, whereas social constructionism lays stress on that social institutions, rules and norms are not nature-like objects but historically and culturally variable human constructions. Both of these versions have been seen to be included in Foucault's thinking. The same is true of Luhmann who worked on his own version of constructionism in the late 1980s and in the 1990s, especially, in his Soziologische Aufklärung. Konstruktivistische Perspektiven (1993) und Die Wissenschaft der Gesellschaft (1991).

Luhmann's constructionism is, among other things, based on George Spencer-Brown's philosophy, as well as on Humberto Maturana's and Fransisco Varela's theoretical biology. Leaning on these various sources he held that human minds are operationally closed or autopoietic systems that handle sense perceptions according to their own principles of operation and by means of conceptual distinctions. Hence, we cannot catch the reality as 
such but only the reality as it shows itself to us; in this way, our knowledge confines itself to the phenomenal world. Our picture of the phenomenal world varies according to the kinds of positions and angles from which we consider it and according to the kinds of distinctions and concepts that we project into it. In Luhmann's opinion, we must necessarily use tools such as these, but every now and then it is reasonable to deconstruct the phenomenal world and to outline it by new and fresh tools. Thus, in our cognitive action we should lay stress on the dialectics of constructing and deconstructing the phenomenal world (Luhmann, 1991, pp. 521, 526-7; 1992, p. 88-90; 1993, p. 31-58).

Literature and art have, Luhmann argued, an important task, since they help us to become aware of the contingent nature of the phenomenal world. They help us to deconstruct existing world views and to construct new world views, besides which they imply that everything that exists in the social world could also exist in another way. According to Luhmann, the latter aspect, an element of social constructionism, is central in modern art and literature, since by utilizing imagination and by creating fictional worlds they hint to that existing social arrangements can be replaced with other kind of arrangements. We may, however, ask whether the talk about this element is fully compatible with Luhmann's constructionist epistemology. Does the element of social constructionism in his conception of art imply that receivers of art are able to compare art's fictional worlds with the reality - or at least with their own views of the reality? Luhmann does not seem to have been aware of this ambiguity in his own thinking concerning literature and art.

Partly for this reason Luhmann's disciple Schmidt has held that Luhmann did not consistently stick to constructionist epistemology. In order to distinguish himself more clearly from Luhmann, Schmidt called his own version of constructionist epistemology radical constructivism. Radical constructivism denies the possibility of objectively true knowledge, but it admits that certain views of the reality can be inter-subjectively approved 
in society or in scientific communities. In contrast to this, Schmidt (1989, p. 409-32; 1995, p. 225) goes on, in modern literature different "models of the world" include strong individual and subjective elements, which is not, however, a negative thing; on the contrary, modern literary communication has been a social space in which individuals have had an opportunity to work on their identity and subjectivity.

Thus, since the mid-20 $0^{\text {th }}$ century epistemological constructionism has had a firm place in literary studies and its neighbor disciplines. Instead of analyzing its possible internal inconsistencies, I would here like to pay attention to its views of modern literature's functions. These views are unspecific. Constructionism has told us that literature is a means to cultivate subjectivity, to outline the world in fresh way and to maintain in society an awareness of the contingent nature of existing social arrangements. These thoughts are certainly approvable, but they cannot characterize sufficiently modern literature's functions in society. In order to be able to do this, we need to clear up in what ways modern literature deals with societal-cultural reality.

\section{Modern literature as a discursive field and practice}

In their epistemology, classical structuralism and post-structuralism have been inclined to ignore the difference between physical reality and societal-cultural reality. To be sure, there is, in Barthes' production, a shift towards semiotic-social practices, but structuralism's other representatives used to analyze literary works as abstract linguistic-narrative entities that manifest human mind's universal and ahistorical ways of structuring the world and human experience. Partly in the same vein, post-structuralists have, in literary studies, favored abstract philosophical questions and, through this, passed over literature's relationships with societal-cultural reality. 
In comparison with post-structuralism, cognitive sciences and their applications in literary studies have had a more positive view of literature's cognitive value. This comes up, for example, in monographs like Peter Stockwell's Cognitive Poetics (2002) and Patrick Colm Hogan's Cognitive Science, Literature and the Arts (2003), as well as in Introduction to Cognitive Cultural Studies (2010), edited by Lisa Zunshine. At the same time one has to admit that unfortunately the societal-cultural dimension is almost entirely missing from Stockwell's and Hogan's monographs. This is not surprising, as the origins of cognitive sciences lie in psychology, linguistics, neurobiology and computer science. On this basis, cognitive sciences have concentrated on considering human mind's ways of perceiving, structuring and interpreting the reality - and when doing this, they have only slightly taken into account the social context in which these activities occur. The book edited by Lisa Zunshine differs from Stockwell's and Hogan's monographs in that its certain articles elaborate upon a more multi-dimensional conception of reality, i.e. a conception that aims at taking into account the specificity of societalcultural reality. This implies that in principle cognitive sciences could be a useful tool for the sociology of literature, although in its present phase it has not yet sufficiently integrated social sciences and cultural studies into its own way of considering the functioning of human mind.

In hermeneutic-phenomenological philosophy and sociology, societalcultural reality has been thought to contain two or even three dimensions. According to Habermas (1973, pp. 188, 289-91), societal-cultural reality differs from physical nature in that it is "symbolically pre-structured"; in other words, collectively shared discourses, meanings, values, rules, norms and world views are its necessary or essential constituents, and not its secondary properties or mere illusory entities. In this way, societal-cultural reality consists of material-social entities (economic-political power structures, communication networks, traffic networks, factories, buildings), as well as of spiritual-social entities (discourses, meanings, values, rules, norms, world 
views). But what about concrete individuals? Do they lie outside society? In his own theoretical model of society, Luhmann excluded concrete individuals or actors from society and, consequently, from the study of society. This stand is, however, questionable, since individuals or actors are historically, culturally and societally determined beings. Therefore, they are equally, at least in part, also constituents of society and proper objects for sociological research.

Post-structuralists have, of course, shared the thought that meanings and discourses are society's essential constituents. In fact, Foucault's entire production is based on this thought. However, what is crucial here is that in their epistemology post-structuralists have not clearly taken it into account. Instead, in their epistemological expressions of opinion they usually write as if there existed only one reality or only a unidimensional world to which we do not have a genuine epistemic access. Hermeneutic social theory, on the other hand, is based on the concept that social agents are not passive marionettes; on the contrary, agents form beliefs, interpretations and valuations concerning society, and in their action agents apply those beliefs, interpretations and valuations and thereby transform them into the reality. It is, in part, just in this way that, for example, societal planning can transform its own vision of society into the reality. As lan Hacking (1999; 2002) states in his moderate constructionism, through this societal-cultural reality is, in part, dependent on agents' ways of giving meanings to this reality. Such being the case, Luhmann and post-structuralists did not see that people's interpretative acts are a constitutive factor in the structure of societal-cultural reality, and, partly for this reason, people have, within certain limits, a genuine knowledge of societal-cultural reality.

Structuralists and post-structuralists have had a passive view of literature. Mikhail Bakhtin's (2007), Hans-Georg Gadamer's (1986), and Hans Robert Jauss' (1984) studies offer, therefore, a more suitable foundation for the sociology of modern literature. These three scholars have understood 
literature as a communicative or discursive practice that stands in a dialogical relation to society and cultural traditions. A starting point in modern literary creation is usually a philosophical, societal, mental or moral problem caused by the societal-cultural development and felt personally important by the author of a literary text. Modern literary works can be held as more or less conscious reactions or answers to problems such as these, and often it is precisely just they that first give a public expression to these problems. When doing this, modern literary works utilize literary and cultural traditions, other discourses and prevalent forms of knowledge. Terry Eagleton (1976), Pierre Macherey (1966), and Raymond Williams (1977) have understood literature in this way as well, but they have more clearly emphasized that as a cultural practice literature is connected to larger societal structures and processes. For them, it participates in discursive struggles between different social classes, fractions, layers and groups; these struggles concern the defining of reality and its phenomena.

The above-presented conception concerns all of the major literary genres - prose, drama, poetry - , although my concrete examples will mainly come from prose and drama. On the basis of the above-presented conception Dadaists and surrealist poems, expressionist plays, T.S. Eliot's poetic work The Waste Land (1922), James Joyce's novel Ulysses (1922), and Hermann Broch's novel trilogy Die Schlafwandler (1931-1932) can be seen as literary and spiritual reactions to the crisis of modern European civilization caused by the First World War. However, different literary genres respond to the rest of society in their own peculiar way. Following Roman Jakobson's (1987) model of linguistic communication, we may say that literary works combine, to a varying extent, representational, expressive and appellative functions. Representational function is usually central in novels and plays, but often these genres, in particularly plays, also aim at directly influencing people's attitudes, values and behavior (appellative 
function). Because poetry concentrates on expressing emotions, attitudes and values, it gives priority to language's expressive function.

Thus, literary works respond to the societal-cultural development in three major ways. (i) They can express the emotions, for example, fear or hope that the development of society arouses in subjects, but it is also possible that (ii) they reflect on this development cognitively and aim at describing it. (iii) And if they appraise this development negatively, they might include explicit or implicit calls for action, i.e. demands to change society. Ways (ii) and (iii) are central in social novels and social plays, as well as in literature with a social purpose ("Tendenzliteratur") and societal novels ("Gesellschaftsromans"). Of these genres, social novels and plays deal with single social phenomena or problems, whereas societal novels aim at offering a wide picture of society. In this article, I mainly analyze representatives of these genres, but it should be borne in mind that, to a lesser extent, these sort of analyzes are meant to be applicable to other literary genres as well.

This conception implies that it is one-sided to consider literature only as a form of knowledge or only from a cognitive standpoint. Literature does not only describe societal-cultural reality and its phenomena; it can equally indicate what sort of order should prevail in this reality. There is always an element of utopia in literature - or, if the authors of literary works are deeply dissatisfied with the prevailing societal order, they might choose a dystopian way of representing it, as, for example, happens in Aldous Huxley's novel Brave New World (1932) and Cormac McCarthy's novel The Road (2006).

As a cultural form and practice, literature participates in the defining, evaluating and, more indirectly, changing of the world. The representations produced by literature can be analyzed from these standpoints. Because literary representations contain evaluative elements, calls for action and limited perspectives to the world, they are not purely mimetic copies of it but interpretations. These features come up, for example, in works dealing with the position of women in society. From Charlotte Brontë's (1816-1858) 
novels Jane Eyre (1847) and Shirley (1849) and Henrik Ibsen's (1828-1906) play Et Dukkehjem (A Doll's House, 1879) to works like Margaret Atwood's (born 1939) novel The Edible Woman (1969) and Toni Morrison's (born 1931) novels Beloved (1987) and Paradise (1997) literature has often represented women as oppressed victims who cannot sufficiently fulfill themselves in society. Literature has defined women's position as a problem that might lead to personal tragedies and that should not be accepted. In the long run, works like these have influenced people's opinions and made them ready to accept changes by which women's position have been improved. Through this, literature has indirectly participated in the changing and producing of societal-cultural reality.

\section{The Concepts of Knowledge and Truth}

Because literary representations include evaluative elements and calls for actions, one could conclude that it is not sensible to apply the concept of knowledge to them. I do not share this conclusion. Instead, I suggest that literary works can offer us knowledge of various kinds. According to traditional and modern epistemology, knowledge can be defined as a true and justified belief. In this definition, theorists of knowledge differentiate three suppositions, namely, that (i) the belief in question is true, (ii) knowing subjects regard it as true and (iii) they have grounds to believe in its truth (See nearer Moser; Nat, 1987). This classical definition of knowledge is chiefly applicable to propositional knowledge, i.e. to the knowledge that concerns states of affairs prevailing in the world and that can be expressed with the sentence formula " $x$ knows that $y$ has such and such properties" (for example, "x knows that our planet is round"). Propositional knowledge differs from procedural knowledge that concerns skills and abilities. Procedural knowledge is expressed by the sentence formula " $x$ knows how $z$ is achieved" (for example, "x knows how to build a house" or "x knows how to analyze 
different world views"). It this sense, procedural knowledge is close to technic or methodic skills.

Both of these forms of knowledge are, in principle, relevant in literature, since modern literary works offer us descriptions of societal-cultural reality and they can teach their readers to analyze different world views and to outline the world in new ways. These achievements can, at least in part, be evaluated with the scale true/untrue. It is, however, uncertain, how well literary works can fulfill the condition (iii) in the classical definition of knowledge. We may, for example, say that Don DeLillo's (born 1936) novel Cosmopolis (2003) contains a certain picture of current economy, especially, of the operation principles of finance capitalism. It presents this picture by telling a fictional story of a young billionaire, whose name is Eric Packer, and of his working day.

Eric has made his huge fortune by speculation in foreign exchange. In his work, he patiently follows changes and oscillations of the exchange rates aiming at benefitting from them financially. This sort of speculation is risk-bearing, for it includes an opportunity to become rich in a moment - or alternatively, a person or a company may lose all of his or its fortune because of an erroneous decision. At the end of the novel, the latter opportunity comes true in Eric's case. In this sense, DeLillo's novel seems to state that Eric's work and current finance economy have dangerously detached themselves from "real economy" and from the production of common good. This alienation-motive repeats several times in DeLillo's novel. For example, in a scene Eric is sitting in the backseat of his luxurious limousine with Vilja Kinski, his "chief of theory", and they are commenting on the demonstration that is surrounding them in streets of New York:

"You know what capitalism produces. According to Marx and Engels". [Vilja Kinski's remark.]

"Its own grave-diggers", he said.

"But these [the demonstrators] are not the grave-diggers. This is the free market itself. These people are a fantasy generated by the market. They 
don't exist outside the market. There is nowhere they can go to be on the outside. There is no outside."

The camera tracked a cop chasing a young man through the crowd, an image that seemed to exist at some drifting distance from the moment.

The market culture is total. It breeds these men and women. They are necessary to the system they despise. They give it energy and definition. They are marketdriven. They are traded on the markets of the world. This is why they exist, to invigorate and perpetuate the system (DeLillo, 2003, p. 89-90).

In the world of this novel, the power of the markets has become omnipresent or total. Even the demonstrators cannot avoid it, since current economy can absorb the critique directed to this economy, productize it and utilize it as a resource of production and marketing. Thus, there is no escape from current market economy. The alienation-motive comes also up in Eric's relation to information technology. Namely, he tends to think that perhaps human beings will, in the near future, change into mere functional components of the economic system and digital flows of information; in this scenario, they might even merge with computers. In addition, Eric's alienation is supplemented by that his social life is extremely poor. His social circle consists mainly of persons to whom he has an instrumental or a non-personal relation. He has a limousine driver, a body guard, a security chief, a personal doctor, a chief of technology, an expert in art, as well as a chief of theory for the explaining of the reality. In this way, Eric has externalized nearly all of his human relationships, and he is not either interested in his young wife and her personality; instead, he has sexual intercourses with other women. In this way, DeLillo's novel emphasizes that current finance economy is in danger of producing an entirely alienated society and an entirely alienated type of human being.

Is this picture true and does the novel justify it? The story of Eric contains both believable and unbelievable elements, but the more important thing here is perhaps that it increases our awareness of the economic, social 
and human risks included in current finance economy. In this sense, the novel at issue undoubtedly has epistemic value. It does not, however, verify its pointed view of current economy. Although the novel contains references to real states of affairs, it is, of course, not a scientific study that operates with wide systematic observations and exact inductive generalizations. At a more general level we may conclude that the knowledge offered by modern literary works is usually not methodically controlled or systematically grounded. In this respect, it often resembles the intuitive or tacit knowledge that social actors have on their society.

It has sometimes been said that when we appraise literature's epistemic value, we should compare literary representations, if possible, with comparable representations produced by the historical and social sciences. In the case of Cosmopolis we should, then, compare its view of current economy and society with the views that have been constructed in the economic sciences, as well as in sociology and social psychology. This kind of comparison has, however, its limits. In fact, the representations produced by the historical and social sciences are often continuously under critical discussion and estimation. It is, therefore, possible that they cannot offer us a widely accepted view of current economy and society. And secondly, it should be borne in mind that, in part, literature's way of dealing with the world differs from that of the historical and social sciences. As Monica Fludernik points out in her Towards a 'Natural' Narratology (1996), a central feature in literature is experientiality. In other words, literature describes the world from the point of view of an experiencing subject. In the case of Cosmopolis, this subject is Eric whose way of experiencing dominates the novel and its narration. Thus, the novel in question describes the world from the standpoint of an alienated subject, and it aims to show that this sort of alienation is caused by current finance economy.

As for literature's evaluative elements, we cannot directly judge them by the scale true/untrue. Following Habermas (1987, p. 434-44), we can state that 
it is sensible to speak about the validity, appropriateness and meaningfulness of values and norms, whereas the scale true/untrue is not here of great importance. Nevertheless, in a certain sense the concept of knowledge is relevant here as well. Namely, when literary works help us to understand what sort of strengths, shortcomings and consequences certain values and norms have, they increase our knowledge of these values and norms.

Indirectly the classical definition of knowledge implies that a belief might be true, even if subjects do not regard it as true or even if they do not believe in its truth. On the other hand, subjects may also regard something as true, although they have only flimsy grounds for this belief and although it might prove to be false later. The latter possibilities are important. Since the days of Max Scheler, sociology of knowledge has been interested in what is accepted as knowledge in society. Sociological perspective to knowledge is also here more fruitful than purely epistemological perspective, since it relates literature's epistemic or cognitive content to literature's societalcultural meaning. It should be mentioned that the correspondence theory of truth - that is, the most common theory of truth - has not taken social factors into account in its definition of truth. Namely, according to this theory a belief is true if it "corresponds to the reality". On the other hand, Habermas' consensus theory of truth relates the problem of truth to the human world. In Habermas' theory, truth is acceptability: thereby, a belief is approved as true if a scientific community or a social community can, with good and justified grounds, accept it as true. Also in this case, a scientific community or a social community might held a belief as true, but later this belief will turn out to be untrue. In his sociology of knowledge, Scheler presented an interesting typology of knowledge. Next I place it to a wider conception of literature's relationships with societal-cultural reality.

When dealing with societal-cultural reality, the authors of literary works start from their own perceptions of this reality and from their own life experience. (a) Thereby literary works contain subjective or personal 
perceptions of the world, but the authors supplement their perceptions and experiences by fictional characters, events and milieus, adjust these contributors to the fluent logic of story-telling and interpret all of these elements by different cognitive frames of references. (b) Consequently, literary works utilize literary conventions and traditions and include references to them. This utilization is not semantically neutral, for it modifies the meanings and representations conveyed by literary works. In addition, literary works lean on different cognitive frames of reference.

In his sociology of knowledge, Scheler mentioned several different cognitive frames of references that might have attained the status of knowledge: (c) religious, metaphysical, natural and historical myths and legends, i.e. the mythical knowledge, (d) the knowledge implicit in everyday natural language, (e) the religious knowledge in its various manifestations, (f) the basic forms of mystical knowledge, (g) philosophical-metaphysical knowledge, (h) the positive knowledge of mathematics, the natural sciences, the humanities and the social sciences and (i) technological knowledge. Scheler $(1980,76)$ adds that each of these types has its own peculiar style and its own use of language; therefore, we can apply the current term "discourses" to them. Similarly, we can speak about a special literary discourse that consists of literary conventions and traditions and literature's ways of dealing with the world; thus, items (a) and (b) describe the operation principles of literary discourse. Undoubtedly Scheler's typology is, in part, obsolete, wherefore it must be supplemented with (j) the common-sense knowledge and ( $k$ ) with the knowledge produced by mass media. Furthermore, often (I) different political or societal ideologies have been regarded as knowledge. This is true of Nazism in Germany in 1933-1945, Marxism-Leninism in the Soviet Union and largely also of the neoliberalist doctrine in current societies. In addition, (m) ethnic or national discourses as well as (n) gender discourses are relevant in the case of modern and contemporary literature. 
Post-structuralism and cultural studies have analyzed literary texts as intersections of discourses. This method is fruitful in the sociology of literature as well. Literary works have a habit of taking certain discourses or cognitive frames of references as granted, without problematizing these discourses, whereas certain other discourses are criticized by them. Thus, literary works are not total negations of the prevalent societal-cultural order, but usually they accept its certain dimensions as self-evident arrangements. This holds true even for the "historical avant-garde" of the early $20^{\text {th }}$ century, i.e. for literary and artistic streams such as Dadaism and surrealism that were critical of modern industrial-capitalist society and the bourgeois way of life but that, at the same time, were strictly male-dominated and metropolisoriented artistic movements.

The next three sub-chapters consider traditional realistic-naturalistic literature and contemporary literature by means of the above-presented distinctions and concepts. It has sometimes been said that traditional realistic-naturalistic literature pays more attention to material-social reality (institutions, habits, social conflicts, people's behavior and their material conditions of living), whereas contemporary literary has concentrated on analyzing and criticizing literary and societal discourses. Although a generalization such as this is in part accurate, it is important to bear in mind that usually literary works deal, to a varying extent, with both of these dimensions of societal-cultural reality.

\section{Traditional realistic-naturalistic literature}

In literary history, the $19^{\text {th }}$ and $20^{\text {th }}$ century realism is also termed "critical realism", since its central topic was the breakthrough of classical laissez-faire-economy or liberal capitalism and the consequences that it caused to the rest of society. In England and France, this breakthrough took place by the 1830s, and in the United States, Germany, Russia and Nordic 
countries in the late $19^{\text {th }}$ century. When considering these topics, authors often saw their own literary creation as an imaginative or "experimental" way of studying society. Hence, they understood themselves as producers of knowledge of society (Claybaugh, 2007; Sicotte, 2013).

As Wolf Lepenies states in his Die Drei Kulturen (1992), at that stage sociology was, actually, only a dawning discipline whose academic position was still unstable. Sociology and realistic-naturalistic literature were, therefore, each other's competitors in the field of societal knowledge. In the $19^{\text {th }}$ century's cultural life, the difference between them was often seen as thin, among other things for the reason that in order to raise their own status both of them aimed to come closer to natural sciences. This holds true, especially, for French and British sociology, as well as for Balzac, Zola and naturalism. The competition between them diluted only in the early $20^{\text {th }}$ century, i.e. at a time when sociology became a legitimate discipline and literature began to draw away from traditional realistic-naturalistic ways of dealing with the world (Lepenies, 1992, p. 1-15).

In contemporary sociology of literature, it is chiefly Jacques Dubois, a Belgian literary historian that has emphasized the affinity between literature and sociology much in the same way as the $19^{\text {th }}$ and the early $20^{\text {th }}$ centuries' literary culture did. For example, in his studies Les Romanciers du réel. De Balzac à Simenon (2000) and Stendhal. Une sociologie Romanesque (2007) he characterizes traditional realistic-naturalistic literature as "a novel-like" form of sociological knowledge (Dubois, 2000, p. 9, p. 62-4; 2007, p. 1122). To this literature he includes several different authors from Stendhal (1784-1842), Balzac and Zola even to Marcel Proust (1871-1922) and Georges Simenon (1903-1989). According to Dubois, from literature such as this we can learn a lot about class relations, power structures, status competition and social habits in French society in the $19^{\text {th }}$ and early $20^{\text {th }}$ centuries. Thus, he seems to hold French realistic-naturalistic literature and empirical social-historical knowledge as kindred phenomena. 
Dubois does not specify his own conception of knowledge, wherefore it is difficult to appraise his views in detail. Likewise, he ignores knowledge's practical implications and he does not either take into account literature's epistemically questionable sides. Nevertheless, it might be easy to agree with him on that Balzac's and Zola's literary production possess obvious epistemic deserts. Namely, these productions contain systematic perceptions and descriptions of the $19^{\text {th }}$ century French society's habits, class differences, values and world views of which Balzac and Zola strived to give an overall picture in their production. Therefore, their production, especially, Balzac's novels have often been seen as the paradigmatic instances of the generic category societal novel. This systematic feature is not surprising, since both of these authors regarded natural sciences as their intellectual model. What is problematic here is that their novels also tend to interpret these perceptions and descriptions by the discourse of natural sciences. Dubois (2000, p. 173) remarks himself as well that Balzac used to compare human society with animal population and he tended to see human society as a special case of nature. He was, actually, an admirer of Étienne Geoffroy Saint-Hilaire (1772-1844), a well-known natural historian who defended an evolutionist standpoint and emphasized the meaning of environment in the evolution of species. Zola, in turn, thought that the life course of an individual is strongly determined by his or her biological genotype and the surrounding social milieu. His novels are thereby "experimentations" that attempt to show what will happen to a person who has a certain biological genotype and who lives in a certain social milieu (See also Boucher, 2013; Dubois, 2000, p. 62-4, p. 230-49).

Thus, Balzac and Zola leant on the $19^{\text {th }}$ century's scientism and its naturalistic view of human society. Their novels give us information of this world view, but we can also interpret this thing negatively. Namely, by reading their novels we can conclude what sort of epistemic distortions authors and people of the $19^{\text {th }}$ century had. In Balzac's and Zola's cases, a 
central epistemic distortion lies in that their novels seem to equate human societies with natural populations, i.e. they do not understand the specificity of human societies. From a methodological standpoint this critique indicates that the sociology of literature needs the help of ideology critique. The necessity of ideology critique rises from that, as Adorno (1980, p. 64-5) noted, false consciousness is a rather regular feature in literature. In the same vein, Pierre Bourdieu (1972) speaks about doxa, i.e. about conceptions and beliefs that have been taken as self-evident truths in society but that are, in fact, often false. In Bourdieu's sociology, the sphere of culture is full of doxa-like beliefs. We may define ideology critique as a procedure that aims to appraise the truth value or validity of the world views and values included in literature. In addition, ideology critique pays attention to the social origin and prevalence of these world views and values.

Ideology critique does not necessarily deny the possibility that literary works can also offer us truthful representations of the world, nor do Adorno and Bourdieu deny this. In the sociologically-oriented study of literature, a more negative stand has been adopted by Eagleton. In his Althusserian phase in the 1970s, Eagleton (1976, pp. 72, 77-80, 112) held that literary works do not refer to "real history"; instead, their referent is "pseudo-real". In other words, literary works show us how people have experienced their life in a given society and in a given historical era, whereas history as such is excluded from literary representations. Eagleton (1976, p. 101) concludes that at its best literature is only capable of revealing how ideology functions in people's minds. His thinking is, however, based on a questionable conception of historical reality. It is not justified to differentiate sharply between history and people's experiences, as people's way of giving meanings to events is a central constituent in societal-cultural and historical reality. Therefore, literature can help us to understand both of these levels or dimensions of the reality.

As for realistic-naturalistic literature's practical meaning, in her study, The Novel of Purpose. Literature and Social Reforms in the Anglo-American 
World (2007), Amanda Claybaugh shows that the connection between literature and social reforms was close in Great Britain and the United States. In these countries, several realist and naturalist authors aimed at representing the social world "as it really is" in order to convince the upper classes of the necessity of profound reforms. The works of those authors dealt, for example, with the slavery and prostitution, the position of women in marriage and society, the position of children in factories and society, the material and spiritual misery of the working class, and the contradictions between social classes and the living conditions in slums (Claybaugh, 2007, p. 1-13, 39-41).

As the examples of reformist works like these Claybaugh mentions, among others, Anne Brontë's The Tenant of Wildefell Hall (1848, alcoholism), Elizabeth Gaskell's Mary Barton (1848, class contradictions), and Harriet Beecher-Stowe's Uncle Tom's Cabin (1851-1852, slavery). Likewise, Claybaugh (2007, p. 52-84) goes on, Charles Dickens had reformist aims almost in all of his works, especially, in The Pickwick Papers (1836-1837, to be imprisoned for debts), Oliver Twist (1837-1838, orphanages), Nicholas Nickleby (1838-1839, conditions in schools), Dombey and Son (1846-1848, arranged marriages, cruelty towards children), and in Bleak House (18521853, defects in the judicial system). They stand for the genre literature with a social purpose or social novel with a purpose.

Speaking more generally, the $19^{\text {th }}$ and $20^{\text {th }}$ centuries' artistic-literary sub-cultures participated in the constructing of reformist and capitalismcritical movements and their collective consciousness. In several countries - not only in Great Britain but also, among others, in France, Germany and Nordic countries - the birth of an organized working-class movement and women's movement took place in a close relation to the formation of a radical press and literary culture; without intellectual and spiritual tools such as these the birth of these movements would have been a much more long-term process. As a representative of this sort of literature, that possessed a profound epistemic, cognitive and practical meaning, we may 
mention Minna Canth (1844-1897), a Finnish author. She belongs to the same generation of the $19^{\text {th }}$ century's Nordic realistic-naturalistic authors as the Norwegian Henrik Ibsen (1828-1906) and the Swedish August Strindberg (1849-1912), and she was strongly influenced by the former. As the examples of her works we may use her novel Köyhää kansaa (Poor People, 1886), as well as her plays Työmiehen vaimo (A Workman's Wife, 1885) and Kovan onnen lapsia (Children of a Hard Fortune, 1888). All of them belong to the category literature with a social purpose.

In spite of its name, A Workman's Wife does not, in the first instance, deal with the miserable position of the working class in the $19^{\text {th }}$ century's society. Its main target is sexual inequality, i.e. distorted power relations between men and women in marriage and society. At that time, Finnish society's legal order gave men a right to control over women's property, for, according to the law, in marriage the entire property of a family belonged under the control of husband. By means of a melodramatic form, A Workman's Wife shows under what kind of arbitrary rule this order could bring women. In this play, the male protagonist (Risto) is a weak character who spends his own earnings and his wife's (Johanna) portion to alcohol and, through this, loses his ability to work. This throws the family into an economic and spiritual misery, which breaks Johanna mentally and physically. Hence, in the end of the play Johanna dies, but - which is an optimistic trait in this dark play - her close friends will take care of her and Risto's little child.

The working-class standpoint is more obvious in Poor people in which a family belonging to the lumpen proletariat is forced to make its living by going begging. Mari, the female protagonist and the mother of this family, is able to endure this situation only by her Christian faith, but when she begins to lose this faith she breaks down mentally. At the end of the play, she has been shut in a mental hospital. Children of a Hard Fortune is perhaps politically the most radical one of Canth's works. In this play, a group of workmen have been building a railway. They will, however, lose this job in the near 
future, which makes them unsure about how they could, after that, support themselves and their families. For these reasons they spontaneously begin a violent rebel against their employers and, finally, against the prevailing societal order as well. At the end of the play, they get, of course, their juridical punishment, but the important thing here is that the play does not condemn them morally. Instead, it considers their acts from several different points of view and, through this, makes them more understandable.

Traditionally, Canth was a controversial figure in Finnish culture. She was appreciated as an artist or as a play and novel writer, but for a long time the official Finnish culture used to regard the above-presented three works as politically questionable. Therefore, to begin it was chiefly the Finnish women's movement and the Finnish labor movement that shared her societal views and accepted them as truthful representations of Finnish society. After the Second World War she has, however, gradually become "the whole Finnish nation's" author. In fact, to a lesser extent, this sort of tension between literature and the rest of society has been rather typical of modern Western culture. Since the late $18^{\text {th }}$ century, literature has been an important area in the producing of fresh and radical attitudes, values and world views. To begin these new attitudes, values and world views have often been maintained by a small intellectual sub-culture, whereas the rest of society has been able to adopt them more widely only in the long run. In this sense, we may even speak about an epistemic gap or a time lag between literature and the rest of society.

\section{Contemporary literature}

In their influential work, Le nouvel esprit du capitalisme (1999), Luc Boltanski and Ève Chiapello speak about two kinds of critique on capitalism: about social and artistic critique. Both of these critiques were born in the $19^{\text {th }}$ century, but, according to the book in question, so far the 1960 s and 
1970s form the last period in which social movements and art were able to radically describe and question the prevailing societal order. After this, social and artistic critique have been in a difficult situation, among other things, for the reason that the collapse of socialist experimentations seems to have make of utopian thinking an obsolete thing. To this explanation, presented by Boltanski and Chiapello, we may add that since the 1980s and 1990s the sphere of art has also increasingly fused with contemporary capitalist economy, which has, in part, made of art an integral element of the current societal order.

To be sure, this partial fusion between current economy and art concerns, primarily, for kinds of art such as architecture, film, music, design and visual art. These kinds have been fused with current capitalist economy - or with current "creative economy" - in a large scale, whereas comparable tendencies have not been equally strong in literature. In this area, there are still authors who continue the tradition of socially sensitive works. Don DeLillo, whose novel Cosmopolis (2003) we considered previously, belongs to this layer, and Michel Houellebecq (born 1956) is this layer's another internationally well-known representative. Although authors like these do not constitute a main stream in contemporary literature, their works indicate that literature is still able to produce epistemically valuable works on societal-cultural reality.

In the $19^{\text {th }}$ century, novels did not usually rely on an essay-form and large philosophical discussions, whereas in current novels these devices are common. For this reason, literature's habit of dealing with societal-cultural reality has become more philosophical by nature. The generalization also concerns socially sensitive works in contemporary literature. For example, Houellebecq's novel Les particules élémentaires (1998) deals with current society by story-telling and philosophical discussion, and its essay-like parts directly criticize the discourses of neoliberal capitalism and sexual liberation. This novel aims to offer an overall interpretation of "the materialistic era" or 
Western modernity that began in the $17^{\text {th }}$ century. Rationalism, individualism and materialistic world view have been its central characteristics of which Houllebecq's novel focus on individualism.

Individualism is, the novel goes on, closely connected to the development of modern capitalist economy. Since the 1960s it has increasingly been by means of "sexual liberation" that this economy has brought the human body and libidinous energy into its use. This process has led to an expansive eroticization or sexualization of society, above all, of the worlds of design, fashion, media, advertising and marketing. In individuals, it had maintained a consumerist-hedonist attitude to the world and other people, which has had a destructive influence on social communities and on the institution of marriage. Therefore, the narrator of the novel is critical of the so-called sexual liberation:

It is startling that sexual liberation is sometimes presented as a communal dream, albeit, in fact, it was only a new step in the historical development of individualism. As one can guess from the beautiful word "the unit of family", the marriage and the family stood for the last islet of primitive communism in liberal society. Sexual liberation led to the destroying of those communal intermediates that still separated the individual from the market forces. This destruction process has continued until our days. (Houellebecq 1998, p. 124).

The discourses promoting neoliberal capitalism and sexual liberation decrease society's internal cohesion and produce alienation in individuals. In particular, they effectively undermine the possibility to attain genuine love and affection in human relationships. Houelleceq's view of current society is, thereby, close to DeLillo's view, although the former gives a much more central position to current capitalism's ability to utilize the world of human sexuality for economic purposes. Yet, the novels of both of these authors represent current society, in a pessimistic way, largely as an alienated social space.

In Les particules élémentaires, the above-presented critique on capitalism is chiefly formulated by the narrator as well as by Bruno and 
Michel Djerzinski, the major characters. Of them Bruno is an ambiguous figure, since he is also addicted to current pornography and he is an active consumer of commercial sexual services. Michel, in turn, is a gifted biologist who, at the end of the novel, elaborates upon a revolutionary procedure by means of which all of the cells can be copied as many times as is wished. This new procedure makes possible the cloning of all of the living species. The philosophy underlying Michel's research work can be formulated as follows: the humankind must disappear and, before that, give birth to a new species that is sexless, immortal and free of individuality (Houellebecq 1998, p. 324).

Houllebecq's fourth novel Possibilité d'une île (2005) can be understood as a continuation to the themes of Les particules élémentaires. This novel combines elements of different literary genres, above all, of philosophical novel, utopia literature and science fiction. The events of the novel occur, on the one hand, close to our era, and, on the other, in the beginning of the 31 st century. In the world of this novel, the old human species is degenerating and diminishing from the globe and it is increasingly replaced by a new human species that reproduces itself by cloning.

In this fictional world, Daniel 1 is still close to our era and our culture, even if he stands for the first generation of a new human species. Hence, he has a lot of "human" properties; for example, he has a rather cynical view of the world, and he is also incapable of loving. In addition, as a millionaire and successful media comic he wishes "to unite pornography's and extreme violence's commercial interests". However, then he tells how, with a dog called Fox, an unselfish or a disinterested love came to his life. Later generations of this new human species detach themselves more clearly from human properties, for example, from feelings such as sorrow, fear of death and sexual desire. Consequently, Daniel 24 is almost free of these feelings, but, instead of them, questions of genuine love are still important for him and other representatives of this new human species. Daniel 24 thinks about feelings in this way: 
Goodness, empathy, loyalty and altruism are, then, continuously unsolved mysteries that, however, can be found from the limited essence of dogs. The possible arrival of The Becoming depends on the solution of this problem. I believe in the arrival of The Becoming (Houellebecq 2005, p. 64).

The motive of genuine love repeats also in a beautiful brief story of Marie 23 who leaves her dwelling and habits and begins to search for love, "a possible island". Questions concerning genuine or disinterested love are important for this new human species, since its members believe that a love such as this is a precondition for the possibility of happiness. How could we, then, appraise this novel? I like to suggest that by speaking about genuine love Possibilité d'une île reflects on values. It wishes to show to what sort of consequences the current marketization of society, as well as the popularity of the hedonistic-individualistic attitude might lead our Western civilization. Houllebecq's novel criticizes this situation by creating a fictional world that functions on the basis of almost entirely different values. Consequently, its epistemic contribution lies chiefly in that it can deepen our understanding of the values that are prevalent in current Western society.

In his novels, Houellebecq has analyzed current society's materialsocial level, as well as its spiritual-social level. The latter aspect, i.e. the level of discourses has been central in certain works of contemporary literature; hence, works such as these function as a meta-discourse to other discourses and reflects on them. This meta-discursive dimension has been important, especially, in Michel Tournier's (born 1924) novels. By rewriting the classical story on Robinson Crusoe, his Vendredi ou des Limbes du Pacifique (1967) appraises the Enlightenment rationalism and Western colonialism by presenting an alternative to them. In this alternative version, Western civilization lives in a balance with other civilizations and with the surrounding nature. Tournier's Le Roi des Aulnes (1970), in turn, deals with the ideology of Nazism. As Hanna Meretoja (2010, p. 181-322) remarks, this novel seems to say that human beings need narratives and myths in order to make sense of the world and 
their own existence, but the case of Nazism shows that this disposition might also lead to destructive consequences if people blindly equate myths with reality. Through this, contemporary literature improves its readers' ability to become aware of different discourses and to critically analyze them.

Meta-discursive reflection may also concern literature itself. In this case, literary works comment on themselves and literary conventions and traditions, just as representatives of nouveau roman and postmodernism - John Barth (born 1930), Jorge Luis Borges (1899-1986), Italo Calvino (1923-1985), Umberto Eco (1932-2016), John Fowles (1926-2005), Thomas Pynchon (born 1937) - have done. This dimension is not, of course, absent in previous literature, but in traditional realistic-naturalistic literature it did not obtain a central position.

Similarly, during last decades literature has deepened its readers' understanding of ethnic or national distinctions, as well as of gender differences in current societies. Salman Rushdie's (born 1947) and Zadie Smith's (born 1975) works are part of the former phenomenon and Margret Atwood, Virginie Despentes (born 1969), and Toni Morrison belong to the latter phenomenon, whereas authors such as James Baldwin (1924-1987), Aurora Levis Morales (born 1954), and Emine Sevgi Özdamar (born 1946), a Turkish-German writer, combine ethnic and gender points of views in their production. Literary studies have usually indirectly presumed that authors like these increase our knowledge of current societies. I share this belief, but what about the social function of these literary layers? Are we justified to assume that they will have a similar social function as the $19^{\text {th }}$ century's realistic-naturalistic literature had, i.e. will also they be able to contribute to social changes in a concrete way? Unfortunately, at present it is prematurely to try to answer to these questions. Usually the epistemic contents, values and calls for action included in literary works have to influence people's minds and attitudes for several generations before they change more widely and more concretely into societal-cultural reality. But at least we can say that at present those literary 
layers, just like Houellebecq's and DeLillo's works, are obviously influencing their individual readers' ways of thinking and dispositions.

\section{Conclusions}

Since the late $20^{\text {th }}$ century, epistemological skepticism and agnosticism, as well as constructionism in its various manifestations have had a firm position in literary studies. Owing to this situation, literature studies has not been capable of elaborating upon a believable view of literature's epistemic value and its functions in society. Although post-structuralism's golden era is now, in part, passé, its successors have not overcome all of its central weaknesses. The same concerns the applications of cognitive sciences in literary studies. They have largely avoided epistemic and epistemological questions, although they can, in principle, be a useful co-operator for the sociology of literature. The article at hands has elaborated upon an alternative way of understanding modern literature. This way sees modern literature as a cognitively valuable discourse on societal-cultural reality. In this task, modern literature has offered us knowledge of society's material and spiritual levels, as well as of people's different ways of experiencing their life in society.

Erkki Sevänen is a Professor of Literature, Sociology of Literature at the School of Humanities, Finnish Language, and Cultural Sciences at the University of Eastern Finland.

Đ erkki.sevanen@uef.fi 


\section{References}

\section{Fiction}

1. CANTH, Minna. Työmiehen vaimo. Näytelmä [A Workman's Wife. A Play]. In: CANTH, Minna. Valitut teokset. Helsinki: WSOY, 1885 [1953].

2. CANTH, Minna. Köyhää kansaa. Pienoisromaani. [Poor People. A Novelette]. In: CANTH, Minna. Köyhää kansaa, Kauppa-Lopo. Lehtori Hellmanin vaimo. Salakari. Agnes. Hämeenlinna: Karisto, 1886 [1983]. p. 5-61.

3. CANTH, Minna. Kovan onnen lapsia. Näytelmä. [Children of a Hard Fortune. A Play] In: CANTH, Minna, Työmiehen vaimo. Kovan onnen lapsia. Vantaa: WSOY, 1888 [2003]. p. 111-207.

4. DELILLO, Don. Cosmopolis. London: Picador, 2003.

5. HOUELLEBECQ, Michel. Les particules élémentaires. Paris: Flammarion, 1998.

6. HOUELLEBECQ, Michel. La possibilite d'une île. Paris: Fyard, 2005.

7. ZOLA, Émile. La Bête humaine. Paris: Gallimard, 1890 [2006].

\section{Research Literature}

8. ADORNO, Theodor W. Standort des Erzählers im zeitgenössischen Roman. In: Theodor W. Adorno, Noten zur Literatur I. Frankfurt: Suhrkamp, 1954 [1980]. p. 61-72.

9. BAKHTIN, Mikhail. The Word in the World. Edited by Graham Pechey. London: Routledge, 2007.

10. BARTHES, Roland. S/Z. Paris: Seuil, 1970.

11. BOLTANSKI, Luc; CHIAPELLO, Ève. Le nouvel esprit du capitalism. Paris: Gallimard, 1999.

12. BOUCHER, Francois-Emmanuel. Balzac, les espèces sociales et la Répresentation du pouvoir èconomique au XIX siècle. In: SICOTTE, Geneviéve et al. Fiction et économie. Representations de l'economie dans la littérature et les arts du spectacle, XIXe-XXIe siècles. Quebec: Presses de I'Université Laval, 2013. p. 61-78.

13. BOURDIEU, Pierre. Esquisse d'une Théorie de la Pratique, précédé de trois études d'ethnologie Kabyle. Genf: S.A. Droz, 1972.

14. CLAYBAUGH, Amanda. The Novel of Purpose. Literature and Social Reform in the Anglo-American World. Ithaca: Cornell University Press, 2007.

15. DERRIDA, Jacques. De la grammatologie. Paris: Les Édtions de Minuit, 1967. 16. DUBOIS, Jacques Les romanciers du reel. De Balzac à Simenon. Paris: Éditions du Seuil, 2000. 
17. DUBOIS, Jacques. Stendhal. Une sociologie Romanesque. Paris: Éditions La Découverte, 2007.

18. EAGLETON, Terry. Criticism and Ideology. A Study in Marxist Literary Theory. London: NLB, 1976.

19. ECO, Umberto. Opera aperta. Milan: Bombiani, 1962.

20. FLUDERNIK, Monica. Towards a "Natural" Narratology. London: Routledge, 1996.

21. FOUCAULT, Michel. Surveiller et punir: naissance de la prison. Paris: Gallimard, 1975.

22. FOUCAULT, Michel. Histoire de la sexualité. La première partie. Paris: Gallimard, 1976.

23. GADAMER, Hans-Georg: Wahrheit und Methode. Grundzüge einer philosophischen Hermeneutik. Tübingen: J.C.B. Mohr (Paul Siebeck), 1986 [1960].

24. HABERMAS, Jürgen. Zur Logik der Sozialwissenschaften. Materialen. Frankfurt: Suhrkamp, 1973 [1970].

25. HABERMAS, Jürgen. Theorie des kommunikativen Handelns. Band 1. Handlungsrationalität und gesellschaftliche Rationalisierung. Frankfurt: Suhrkamp, 1987 [1981].

26. HACKING, lan. The Social Construction of What? Cambridge: Harvard University Press, 1999.

27. HACKING, lan. Historical Ontology. Cambridge: Harvard University Press, 2002.

28. HARTMAN, Geoffrey. Criticism in the Wilderness. The Study of Literature Today. New haven: Yale University Press, 1980.

29. HERMAN, David. Introduction. In: HERMAN, David (ed.). Narrative Theory and the Cognitive Sciences. Stanford: SCLI Publications, 2003a.

30. HERMAN, David. Stories as a Tool for Thinking. In: HERMAN, David (ed.). Narrative Theory and the Cognitive Sciences. Stanford, California. SCLI Publications, 2003b.

31. HOGAN, Patrick Colm. Cognitive Science, Literature, and the Arts. A Guide for Humanists. London: Routledge, 2003.

32. JAKOBSON, Roman. Language in Literature. Edited by Krystyna Pomorska and Stephen Kudy. Cambridge: Belknap, 1987.

33. JAUSS, Hans Robert. Ästhetische Erfahrung und literarische Hermeneutik. Frankfurt: Suhrkamp, 1984.

34. LEPENIES, Wolf. Between Literature and Science. The Rise of Sociology. Original title: Die Drei Kulturen. Translated by R.J. Hollingdale. Cambridge: Cambridge University Press, 1992. 
35. LUHMANN, Niklas. Die Wissenschaft der Gesellschaft. Opladen: Westdeutscher Verlag, 1991.

36. LUHMANN, Niklas. Beobachtungen der Moderne. Opladen: Westdeutcher Verlag, 1992.

37. LUHMANN, Niklas. Soziologische Aufklärung 5. Konstruktivistische Perspektiven. Opladen: Westdetscher Verlag, 1993.

38. MACHEREY, Pierre. Pour une théorie de la production littéraire. Paris: Maspero, 1966.

39. MAN, Paul de. Allegories of Reading. Figural language in Rousseau, Nietzsche, Rilke and Proust. New haven: Yale University Press, 1979.

40. MERETOJA, Hanna. The French Narrative Turn. From the Problematization of Narrative Subjectivity in Alain Robbe-Grillet's Dans le labyrinth to its Hermeneutic Rehabilitation in Michel Tournier's Le Roi des Aulnes. Turku: Universidade de Turku, 2010.

41. MINK, Louis O. History and Fiction as Modes of Comprehension. New Literary History, v. 1, 1970.

42. MOSER, Paul K.; NAT, Arnold Vander. Human Knowledge. Classical and Contemporary Approaches. Oxford: Oxford University Press, 1987.

43. NIETZSCHE, Friedrich. On Truth and Lies in a Nonmoral Sense. Original title: Über Wahrheit und Lüge im aussermoralischen Sinn [1873]. In: PEARSON, Keith Ansell; LARGE, Duncan. The Nietzsche Reader. London: Blackwell, 2006. p. 114-23.

44. NORRIS, Christopher 1988: Paul de Man. Deconstruction and the Critique of Aesthetic Ideology. London: Routledge, 1988.

45. PIKETTY, Thomas. Capital in the Twenty-First Century. Original title: Le capital au XXI siècle [2013]. Translated by Arthur Goldhammer. Cambridge: The Belknap Press of Harvard University Press, 2014.

46. SCHELER, Max. Problems of a Sociology of Knowledge. Translated by Manfred S. Frings. Edited and with an introducton by Kenneth W. Stikkers. London: Routledge, 1980.

47. SCHMIDT, Siegfried. Die Selbstorganisation des Sozialsystems Literatur im 18. Jahrhundert. Frankfurt: Suhrkamp, 1989.

48. SCHMIDT, Siegfried J. Konstruktivismus, Systemtheorie und Empirische Literaturwissenschaft. In: BERG, Henk de; PRANGEL, Matthias (eds.). Differenzen. Systemtheorie zwischen Dekonstruktionismus and Konstruktionismus. Tübingen: Francke, 1995.

49. SICOTTE, Geneviéve et al. (eds.). Fiction et économie. Representations de I'economie dans la littérature et les arts du spectacle, XIXe-XXIe siècles. Quebec: Presses de I'Université Laval, 2013. 
50. STOCKWELL, Peter. Cognitive Poetics. An Introduction. London: Routledge, 2002.

51. STRAWSON, Galen. Against Narrativity. Ratio v. 17, n. 4, p. 428-52, 2004.

52. WHITE, Hayden. The Content of Form. Narrative Discourse and Historical Representation. Baltimore: The Johns Hopkins University Press, 1987.

53. WILLIAMS, Raymond. Marxism and Literature. London: Oxford University Press, 1977.

54. ZUNSHINE, Lisa (ed.). Introduction to Cognitive Cultural Studies. Baltimore: The Johns Hopkins University Press, 2010. 